\title{
Influence of follicular health on the steroidogenic and morphological characteristics of bovine granulosa cells in vitro
}

\author{
K. M. Henderson, K. P. McNatty, P. Smith, M. Gibb, L. E. O'Keeffe, S. \\ Lun, D. A. Heath and M. D. Prisk
}

Wallaceville Animal Research Centre, Research Division, Ministry of Agriculture and Fisheries, Private Bag, Upper Hutt, New Zealand

\begin{abstract}
Summary. In 24-h cultures, steroid production by cells from non-atretic follicles increased with increasing follicular diameter. Cells from atretic follicles, of all sizes, produced low amounts of oestradiol-17 $\beta$, but very high amounts of progesterone, relative to cells from non-atretic follicles. Increasing the culture period to $72 \mathrm{~h}$ caused little change in daily progesterone and oestradiol-17 $\beta$ production by granulosa cells from atretic follicles. In contrast, in cells from non-atretic follicles, daily progesterone production increased and daily oestradiol-17 $\beta$ production decreased to the levels observed with cells from atretic follicles. Dibutyryl cyclic AMP (1.0 mM) significantly stimulated progesterone production by cells from atretic, but not from non-atretic, follicles. Testosterone $(1 \mu \mathrm{g} / \mathrm{ml})$ had no effect on progesterone production by cells from atretic follicles, while oestradiol-17 $\beta$, oestrone, testosterone, androstenedione and $5 \alpha$-dihydrotestosterone $(0-1000 \mathrm{ng} / \mathrm{ml})$ each significantly suppressed progesterone production by cells from non-atretic follicles in a dose-dependent manner.

Morphometric analysis revealed few subcellular differences between cells from nonatretic and atretic follicles. Mean cell volume was significantly higher for cells from atretic compared to non-atretic follicles, but the mean volumes of the major subcellular components were not influenced by follicle health. The mean surface area of the plasma and nuclear membrane, and granular endoplasmic reticulum was also significantly higher in cells from atretic compared to non-atretic follicles.
\end{abstract}

\section{Introduction}

Oestradiol-17 $\beta$ and progesterone are the two major steroids produced by bovine granulosa cells. Previous studies have shown that oestradiol-17 $\beta$ production by bovine granulosa cells in vitro is related to follicle size and health (Henderson et al., 1984; McNatty et al., 1984a). However, no information is available about how progesterone production by bovine granulosa cells in vitro is influenced by these follicular characteristics. Progesterone concentrations in follicular fluid of follicles collected during the follicular phase before the ovulatory LH surge are significantly higher in atretic than in non-atretic follicles, irrespective of follicle size (Bellin \& Ax, 1984; McNatty et al., 1984a; Kruip \& Dieleman, 1985). As granulosa celis may be a source of progesterone in follicular fluid, it is possible that follicle health may influence progesterone production by granulosa cells. This possibility was examined in the present study which was undertaken to examine the relationship(s) between follicular health and size, and progesterone and oestradiol-17 $\beta$ production by bovine granulosa cells in vitro. In addition, morphometric analysis of granulosa cells was performed to determine whether any morphological characteristics of granulosa cells were related to follicle health. Except for one experiment, granulosa cells were obtained from the ovaries of regularly cyclic Angus cows at known days between Days -4 and +1 of the oestrous cycle 
(oestrus $=$ Day 0). The days were chosen in an attempt to assess what effects (if any) the period during which final follicular preovulatory maturity is attained has on granulosa cell function in vitro. In one experiment, ovaries were obtained from cows (breed and stage of oestrous cycle unknown) slaughtered in a local abattoir.

\section{Materials and Methods}

Reagents. Testosterone, androstenedione, 5 $\alpha$-dihydrotestosterone, oestradiol-17 $\beta$, oestrone and dibutyryl cyclic AMP were obtained from Sigma Chemical Co., St Louis, MO, U.S.A. Cyanoketone (2 $\alpha$-cyano-4,417a-trimethyl-17ß-hydroxy-5-androsten-3-one) was a gift from the late Professor G. S. Boyd (Department of Biochemistry, University of Edinburgh, U.K.). Gonadotrophins (NIH-LH-B10 and NIH-FSH-S15) were obtained from the NIADDK, National Institutes of Health, Bethesda, U.S.A.

Cows and ovaries. Twenty-three Angus cows were grazed on open pasture with a vasectomized bull and examined twice daily for signs of oestrus. Ovariectomy was performed between Days -4 and +1 of the oestrous cycle (oestrus = Day 0 ). The day of the cycle was initially calculated from knowledge of the previous mean oestrous cycle length and date of last oestrus. This dating was subsequently confirmed or modified from details of the histology of the corpus luteum (CL), the weight of the CL, the binding characteristics of ${ }^{125}$ I-labelled human chorionic gonadotrophin to homogenized luteal tissue and the progesterone secretory characteristics of dispersed luteal cells during 3-h incubation in vitro, as described previously (McNatty et al., 1984a). Overall, 2 cows were judged to be at Day -4 of the cycle, 5 at Day $-3,5$ at Day $-2,4$ at Day $-1,5$ at Day 0 and 2 at day +1 .

Ovarian dissections. Pairs of ovaries from the Angus cows were treated as follows. Under a dissecting microscope ( $\times 10-40$ magnification) all antral follicles $\geqslant 2.0 \mathrm{~mm}$ in diameter and corpora lutea were individually dissected out of each pair of ovaries into sterile Medium 199 with Earle's salts (Eagle, 1959) supplemented with Hepes buffer (20 mM), L-glutamine ( $2 \mathrm{~mm}$ ), gentamicin $(50 \mu \mathrm{g} / \mathrm{ml})$ (Gibco, Grand Island, NY, U.S.A.), sodium heparin ( $50 \mathrm{i} . \mathrm{u} . / \mathrm{ml})$ (Weddel Pharmaceuticals Ltd, London, U.K.) and $0.1 \%$ bovine serum albumin (Fraction V, Sigma Chemical Co., St Louis, MO, U.S.A.) (Medium A). After recording the follicular diameter to the nearest $0.5 \mathrm{~mm}$ and examining the thecal vasculature, the follicle was incised to release the contents. The released follicular fluid was examined for the presence or absence of debris and then aspirated through a fine-bore capillary tube. The internal follicle wall was washed gently and repeatedly with $2 \mathrm{ml}$ Medium A and the released clumps of granulosa cells were dispersed by pipetting several times through a finely drawn Pasteur pipette. The oocyte was isolated and assessed subjectively as being healthy or degenerate as previously described (McNatty et al., 1983). The follicle wall was washed several more times, and the total number of granulosa cells in the pooled washings was counted by using a haemocytometer, and their viability was determined by uptake of nigrosin dye. The colour of the theca interna was noted. Ovaries obtained from the abattoir were treated as above except that only follicles $\geqslant 10 \mathrm{~mm}$ in diameter were recovered.

Follicle classification. Each follicle was classified as non-atretic, intermediate or atretic on the basis of its morphological appearance. Details of the follicle classification scheme have been described previously (McNatty et al., 1984a). Follicles considered to be non-atretic were those with: visible thecal capillaries when viewed at $\times 10$ magnification under a dissecting microscope; no debris in the follicular fluid; $>75 \%$ of the expected maximum number of granulosa cells for a given follicle size; a healthy looking oocyte; and a pink to red theca interna. Intermediate follicles had the same characteristics as non-atretic follicles except that the theca interna was white. All other follicles were considered to be atretic.

Granulosa cell cultures. To obtain sufficient granulosa cells from each pair of Angus cow ovaries for replicate cultures, it was often necessary to pool cells from follicles of a similar size and classification, particularly for small and/or atretic follicles. In the experiment using abattoir material, granulosa cells were pooled from non-atretic follicles $\geqslant 10 \mathrm{~mm}$ in diameter until a sufficient number of cells had been obtained. After collecting the granulosa cells, and pooling when appropriate, the cells were centrifuged at $200 \mathrm{~g}$ for $10 \mathrm{~min}$, resuspended in Medium A devoid of sodium heparin, Hepes and bovine serum albumin, but containing $10 \%$ newborn calf serum (Gibco) (Medium B) and recounted. Aliquants of approximately 100 to $600 \times 10^{3}$ 'live' granulosa cells in $0.5 \mathrm{ml}$ Medium B were pipetted into individual wells of multi-welled tissue-culture Petri dishes (Sterilin, Middlesex, U.K.). In some instances the wells contained an $18 \mathrm{~mm}^{2}$ glass cover-slip for attachment of the cells. A further $0.5 \mathrm{ml}$ Medium B either alone or containing added steroid, dibutyryl cyclic AMP or gonadotrophin was added and the cells were incubated at $37^{\circ} \mathrm{C}$ in a humidified atmosphere of $5 \% \mathrm{CO}_{2}$ in air. Steroids were added to the culture medium in ethanol or acetone; the concentration of organic solvent in the culture medium never exceeded $1 \%$. Control cultures received vehicle alone. For each Angus cow 2-4 replicate cultures for each treatment were establishd. Cultures of cells for $24 \mathrm{~h}$ were established for all 23 cows, and when there were sufficient cells (which occurred with about half the cows) 72-h cultures were also established. In the 72-h cultures, the medium was renewed every $24 \mathrm{~h}$ with the spent media being stored frozen. At the end of the culture period the cells were washed thoroughly with Medium B devoid of serum, and then either stored frozen until assayed for protein by the method of Lowry et al. (1951) as modified by Patterson (1979), or processed for scanning electron microscopy. 
Scanning electron microscopy. Granulosa cells attached to glass cover-slips were immersion-fixed for $1 \mathrm{~h}$ at $4^{\circ} \mathrm{C}$ in $2 \%$ glutaraldehyde in $0.1 \mathrm{M}$-cacodylate buffer $(\mathrm{pH} .7 \cdot 4)$, and post-fixed for $1 \mathrm{~h} \mathrm{in} \mathrm{l} \%$ osmium tetroxide in $0.1 \mathrm{M}$ cacodylate buffer. The cells were then dehydrated in ethanol, critical point-dried using liquid $\mathrm{CO}_{2}$ and then platinumcoated in a Polaron E5100 coating unit (Polaron Equipment Ltd., Watford, U.K.). The cells were viewed in a Super III-A scanning electron microscope (International Scientific Instruments Inc, Santa Clara, CA, U.S.A.).

Transmission electron microscopy. Freshly collected granulosa cells from non-atretic, intermediate and atretic follicles were immersion-fixed for $1 \mathrm{~h}$ at $4^{\circ} \mathrm{C}$ in $2.5 \%$ glutaraldehyde in $0.1 \mathrm{M}$-cacodylate buffer (pH 7.4). The cells were then pelleted by centrifugation and encased in 3\% agar. After rinsing with $0.1 \mathrm{M}$-cacodylate buffer, the cells were post-fixed for $1 \mathrm{~h}$ in $0.1 \mathrm{M}$-cacodylate-buffered $1 \%$ osmium tetroxide. After further rinsing, the cells were stained en bloc with $2 \%$ aqueous uranyl acetate, dehydrated through a graded series of ethanol solutions and embedded in Spurr's resin. Thin (silver) sections were cut at intervals throughout the depth of the cell pellets, stained with uranyl acetate and Reynold's lead citrate and viewed in a Philips 201 transmission electron microscope (Philips, Eindhoven, The Netherlands). Thicker sections $(1 \mu \mathrm{m})$ were also cut, and stained with methylene blue for determination of cell volumes.

Morphometric analysis. Volume density (organelle volume per unit cell volume) and surface density (surface area of the membrane per unit cell volume) were determined from electron micrographs at a final magnification of $\times 14500$. The cells for study were chosen randomly: $2-3$ micrographs of each cell were prepared and over the 3 classes of follicle health 296 cells were studied. Volume density was determined by lineal analysis as described by Williams (1977). Surface density was determined using uni-direction linear probes as described by Weibel (1980a). For both determinations a sufficient number of measurements was made so that the values of the relative standard errors were $\leqslant 5 \%$ (Weibel, 1980a). Determination of cell volume allowed the volume and surface density values to be expressed as organelle volume and membrane surface area per granulosa cell.

Cell volumes were calculated from light photomicrographs of methylene blue-stained sections of freshly isolated granulosa cells, using the equations described by Abercrombie (1946) and Williams \& Cope (1981). At least 200 nuclear transections were measured for each determination.

Calculation of the numerical density $\left(\mathrm{N}_{\mathrm{V}}\right)$ of mitochondria was based on the formula described by Weibel (1980b) in which $\mathrm{N}_{\mathrm{v}}=k / \beta \times\left(\mathrm{N}_{\mathrm{A}}\right)^{3 / 2} /\left(\mathrm{V}_{\mathrm{v}}\right)^{1 / 2}$ whereV $\mathrm{V}_{\mathrm{v}}=$ volume density of mitochondria; $\mathrm{N}_{\mathrm{A}}=$ number of profiles per unit section area; $\beta=$ shape coefficient and $k=$ size distribution coefficient based on the size distribution of the mean tangent diameter.

Radioimmunoassays. The concentrations of progesterone, pregnenolone and oestradiol-17 $\beta$ were measured without extraction in aliquants of granulosa cell culture medium using specific radioimmunoassays described previously (Henderson et al., 1983; McNatty et al., 1984b). The limit of sensitivity of the assays (per tube) was $25 \mathrm{pg}$ for progesterone, $50 \mathrm{pg}$ for pregnenolone and $5 \mathrm{pg}$ for oestradiol-17ß. The intra- and inter-assay coefficients of variation were $<10 \%$. Steroid concentrations in the culture media were normalized with respect to the protein content of the granulosa cells at the end of the culture period, and the results were expressed as ng steroid/mg protein. For each Angus cow, the coefficient of variation between replicate cultures having the same treatment ranged between 6 and $27 \%$.

Statistics. For the Angus cows, average values were calculated for each cow and these values were then used to calculate group means, or geometric means for $(\mathrm{N})$ cows. With the cultures established from a single pool of granulosa cells from abattoir ovaries, mean values were calculated for replicate cultures of each treatment. Further statistical analysis was performed using analysis of variance in conjunction with either the Newman-Keuls multiple range test, when making comparisons between mean values over all groups, or with Dunnett's test when comparing a control (untreated) group mean value with each of the other treatment group means. When heterogeneity of variance was indicated by Bartlett's test, the data were transformed to logarithms to equalize the variances before statistical analysis. In these instances, the data have been presented as geometric means together with $95 \%$ confidence limits. The level of significance was set at $P<0.05$.

\section{Results}

Basal production of progesterone was measured in cultures not receiving any exogenous steroid or gonadotrophin. Oestradiol-17 $\beta$ production was measured in cultures receiving testosterone $(1 \mu \mathrm{g} / \mathrm{ml})$. This dose of testosterone allowed production of maximum amounts of oestradiol-17 $\beta$. No detectable amounts of oestradiol- $17 \beta$ were produced by cultures devoid of exogenous testosterone. In a preliminary study, granulosa cells before and after culture were extracted with ethanol to measure steroid content, but no detectable amounts of progesterone or oestradiol-17 $\beta$ were found. 
Table 1. Progesterone and oestradiol- $17 \beta$ production by bovine granulosa cells with respect to follicular health and diameter

\begin{tabular}{llccc}
\hline & & \multicolumn{3}{c}{ Follicular diameter (mm) } \\
\cline { 3 - 5 } Steroid & Follicle health & $<5$ & $\geqslant 5-<10$ & $\geqslant 10$ \\
\hline Progesterone & Non-atretic & $76^{\mathrm{c}}(10)$ & $175^{\mathrm{b}}(23)$ & $290^{\mathrm{a}}(11)$ \\
(ng/mg protein) & & $50-115$ & $131-233$ & $220-381$ \\
& Intermediate & $113^{\mathrm{c}}(13)$ & $131^{\mathrm{b}, \mathrm{c}}(8)$ & - \\
& & $60-209$ & $79-217$ & \\
& Atretic & $1094^{\mathrm{d}}(23)$ & $1412^{\mathrm{d}}(5)$ & $1455^{\mathrm{d}}(3)$ \\
& & $906-1322$ & $785-2536$ & $392-5383$ \\
\hline Oestradiol-17ß & Non-atretic & $122^{\mathrm{c}}(4)$ & $209^{\mathrm{c}}(17)$ & $1357^{\mathrm{a}}(11)$ \\
(ng/mg protein) & & $17-855$ & $90-475$ & $633-2899$ \\
& Intermediate & $71^{\mathrm{c}}(7)$ & $116^{\mathrm{c}}(4)$ & - \\
& & $16-310$ & $19-698$ & \\
& Atretic & $31^{\mathrm{c} . \mathrm{d}}(19)$ & $14^{\mathrm{d}}(4)$ & $17^{\mathrm{d}}(3)$ \\
& & $22-44$ & $8-24$ & $11-24$ \\
\hline
\end{tabular}

Cells were cultured for $24 \mathrm{~h}$. Values are geometric means with $95 \%$ confidence limits below for $(\mathrm{N})$ cows. Values not sharing a common superscript in the same row or column are significantly different ${ }^{\mathbf{a b}} P<0.05$; others, $P<0.01$.

Influence of follicular health and size on progesterone and oestradiol-178 production by granulosa cells cultured for $24 \mathrm{~h}$

Mean production of progesterone and oestradiol-17 $\beta$ by granulosa cells from non-atretic follicles increased significantly as follicular diameter increased (Table 1). At all follicle diameters, progesterone production by cells from atretic follicles was significantly higher than that of cells from non-atretic follicles. Oestradiol- $17 \beta$ production by granulosa cells from atretic follicles $\geqslant 5 \mathrm{~mm}$ in diameter was significantly less than that of cells from non-atretic follicles of a similar size. These effects of follicle health and size were independent of the days of the oestrous cycle studied. The highest production of progesterone was, however, observed with cells recovered on Day +1 from two haemorrhagic presumptive preovulatory follicles (10 and $11 \mathrm{~mm}$ diam.). The cells from these follicles produced 6-7 $\mathrm{g}$ grogesterone $/ \mathrm{mg}$ protein when cultured for $24 \mathrm{~h}$.

Influence of follicle health on progesterone, pregnenolone and oestradiol-17 $\beta$ production by granulosa cells cultured for $72 \mathrm{~h}$

During $72 \mathrm{~h}$ of culture, there was a $\sim 5$-fold increase in the mean daily production of progesterone by granulosa cells from non-atretic follicles (Fig. 1). In contrast, mean daily production of progesterone by granulosa cells from atretic follicles changed little during $72 \mathrm{~h}$ of culture. This effect of follicular health was not related to follicle size or day of the cycle (Days -4 to 0 ). When the effects of LH, FSH, LH + FSH (100 and $1000 \mathrm{ng} / \mathrm{ml}$ of each) or dibutyryl cyclic AMP (0.1 and $1.0 \mathrm{~mm})$ or testosterone $(1 \mu \mathrm{g} / \mathrm{ml})$ on progesterone production were examined, testosterone and dibutyryl cyclic AMP (1.0 mM) were the only treatments to have a significant effect, relative to untreated cultures. Testosterone significantly inhibited progesterone production by granulosa cells from non-atretic and intermediate follicles after the first $24 \mathrm{~h}$ of culture, but had no effect on cells from atretic follicles (Fig. 1). Dibutyryl cyclic AMP stimulated significantly progesterone production by cells from atretic follicles, but had no effect on cells from non-atretic and intermediate follicles (Fig. 1).

The differences in the amounts of progesterone produced by cells from non-atretic and atretic follicles during the first $24 \mathrm{~h}$ of culture (Table 1; Fig. 1) might have arisen from differences in the ability of the cells to metabolize progesterone further, or to synthesize its precursor pregnenolone. 

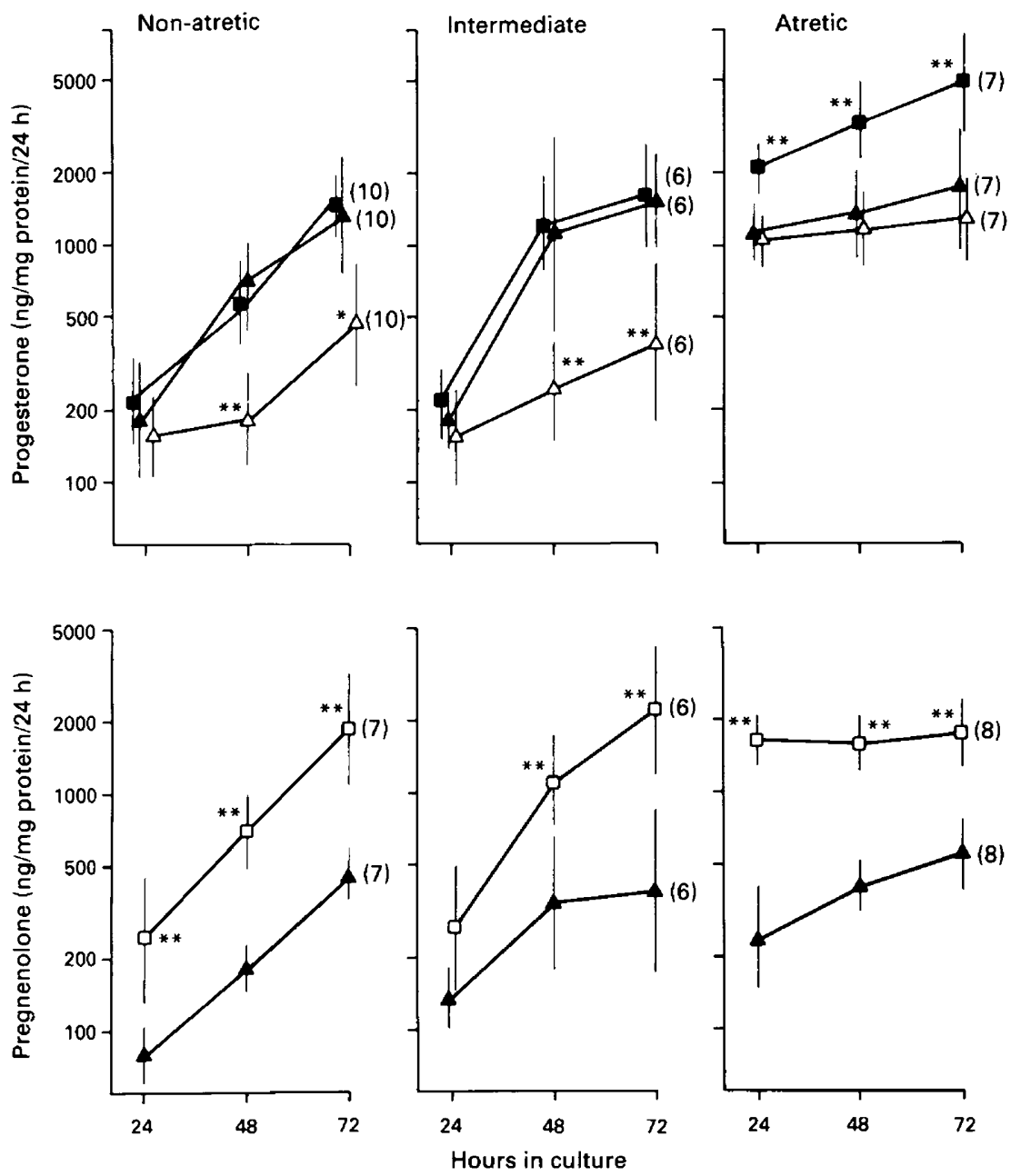

Fig. 1. Progesterone and pregnenolone production by granulosa cells from non-atretic, intermediate and atretic follicles cultured for $72 \mathrm{~h}$. Values are geometric means with $95 \%$ confidence limits for (N) cows. $\Delta, \triangle, \square$ and $\square$ refer to untreated (control), testosterone $(1 \mu \mathrm{g} / \mathrm{ml}$ ), dibutyryl cyclic AMP $(1.0 \mathrm{~mm})$ and cyanoketone $(1 \mu \mathrm{g} / \mathrm{ml})$-treated cultures respectively. ${ }^{*} P<0.05 ;{ }^{* *} P<0.01$ : geometric mean values significantly different from corresponding untreated (control) values.

To test this possibility cells were cultured in the presence of cyanoketone, an inhibitor of $3 \beta-$ hydroxysteroid dehydrogenase. Preliminary dose-response studies established that, at a dose of $1 \mu \mathrm{g}$ cyanoketone $/ \mathrm{ml}$, progesterone production was $<12 \%$ of that produced by untreated cultures, while pregnenolone production was comparable to that of progesterone produced by untreated cultures. Irrespective of follicle size, the changes in cellular pregnenolone production in cyanoketone and untreated cultures (Fig. 1, lower half), were similar, with respect to follicle health and time in culture, to those observed for progesterone in untreated cultures (Fig. 1, top half).

Mean daily production of oestradiol- $17 \beta$ (in the presence of $1 \mu \mathrm{g}$ testosterone $/ \mathrm{ml}$ ) by granulosa cells from atretic follicles of all sizes changed little during $72 \mathrm{~h}$ of culture, remaining at about $10-20 \mathrm{ng} / \mathrm{mg}$ protein $/ 24 \mathrm{~h}$. During the first $24 \mathrm{~h}$ of culture, mean production of oestradiol- $17 \beta$ by granulosa cells from non-atretic and intermediate follicles $\geqslant 5 \mathrm{~mm}$ diameter was significantly higher than that of cells from atretic follicles (Table 1). However, over the next $24 \mathrm{~h}$ of culture, 


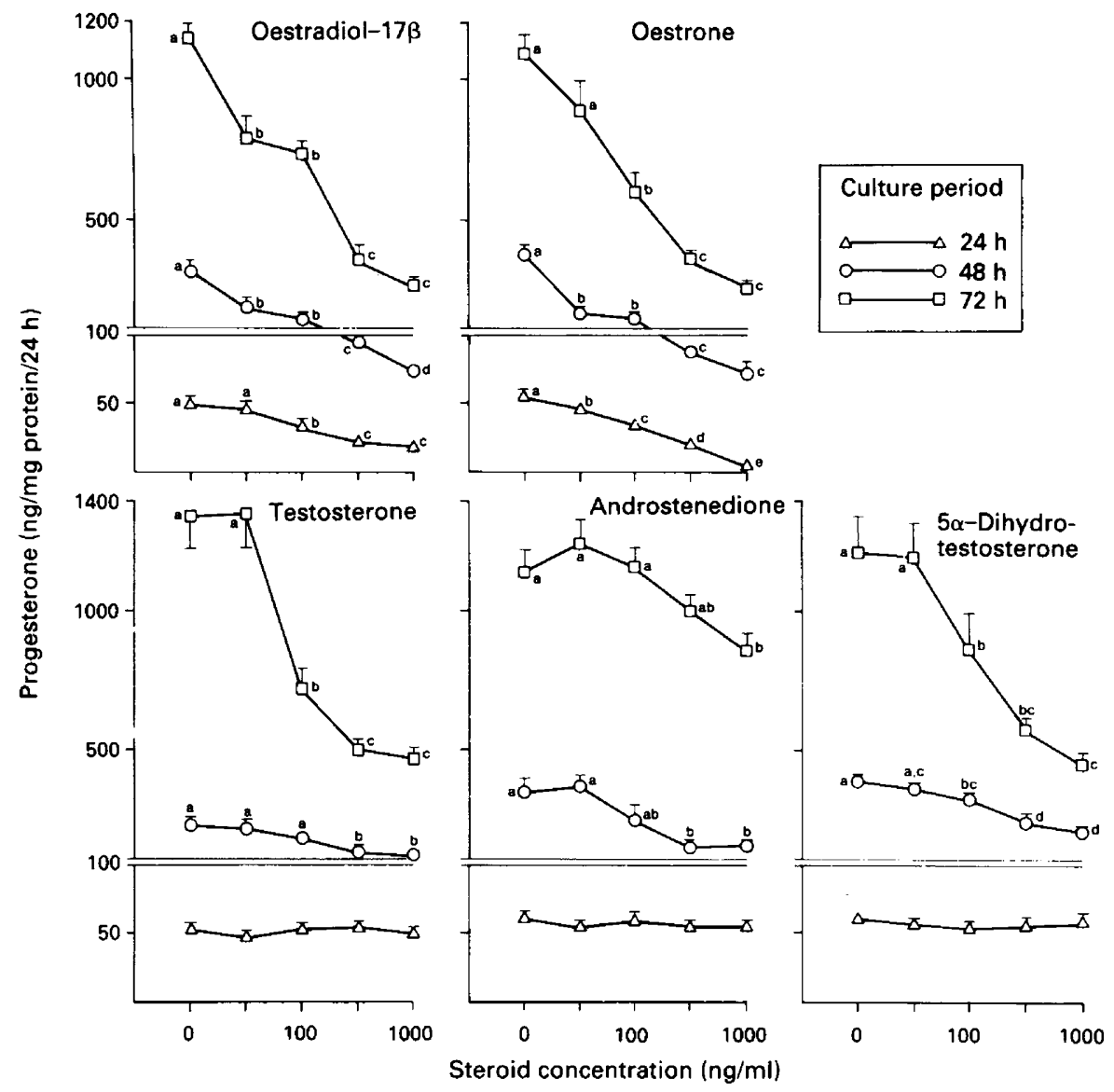

Fig. 2. Effect of oestrogens and androgens on progesterone production by granulosa cells cultured for $72 \mathrm{~h}$. Values are arithmetic means of 4 replicate cultures. Vertical lines show the s.e.m. when larger than the size of the symbol. Mean values not sharing a common letter superscript over the same culture period are significantly different $(P<0.05)$. Groups of mean values without superscripts are not significantly different.

production of oestradiol-17ß by cells from non-atretic and intermediate follicles had fallen to $<10 \%$ of their original values, and within $48 \mathrm{~h}$ had fallen to levels no different from that of cells from atretic follicles. This decline in daily production of oestradiol-17 $\beta$ could not be prevented by culturing the cells in the presence of $1 \mu \mathrm{g}$ testosterone $/ \mathrm{ml}$ with FSH $(100$ or $1000 \mathrm{ng} / \mathrm{ml})$ or with $\mathrm{LH}$ $(100 \mathrm{ng} / \mathrm{ml})$ or with dibutyryl cyclic AMP $(1.0 \mathrm{~mm})$.

Effect of oestrogens and androgens on progesterone production by granulosa cells from non-atretic follicles

In view of the finding that testosterone could inhibit progesterone production by granulosa cells from non-atretic and intermediate follicles, we decided to test the effects of some other ovarian steroids. Because no more Angus cows were available, and because of the large numbers of cells required, the ovaries for this part of the study were obtained from cows (breed and stage of oestrous cycle unknown) slaughtered at a local abattoir. A single pool of granulosa cells from large $(\geqslant 10 \mathrm{~mm}$ diam.), non-atretic follicles was obtained. Figure 2 shows the effect of oestradiol-17, oestrone, testosterone, androstenedione and $5 \alpha$-dihydrotestosterone on progesterone production 
Table 2. Influence of follicular health on cell volume and surface area of subcellular components, and numerical density of mitochondria of preculture granulosa cells

\begin{tabular}{lccc}
\hline & \multicolumn{3}{c}{ Follicular health } \\
\cline { 2 - 4 } & Non-atretic & Intermediate & Atretic \\
\hline Cell volume $\left(\mu \mathrm{m}^{3}\right)$ & $537^{\mathrm{a}}$ & $745^{\mathrm{b}}$ & $784^{\mathrm{b}}$ \\
& $456-617$ & $681-809$ & $650-918$ \\
Subcellular components & & & \\
Mitochondria & $82^{\mathrm{a}}$ & $91^{\mathrm{a}}$ & $128^{\mathrm{a}}$ \\
(no./cell) & $63-100$ & $65-117$ & $85-171$ \\
Plasma membrane & $916^{\mathrm{a}}$ & $1198^{\mathrm{b}}$ & $1383^{\mathrm{c}}$ \\
$\left(\mu \mathrm{m}^{2} /\right.$ cell) & $860-972$ & $1109-1285$ & $1296-1469$ \\
Nuclear membrane & $548^{\mathrm{a}}$ & $753^{\mathrm{b}}$ & $883^{\mathrm{b}}$ \\
$\left(\mu \mathrm{m}^{2} /\right.$ cell) & $498-598$ & $685-821$ & $816-950$ \\
Outer mitochondrial & $694^{\mathrm{a}}$ & $674^{\mathrm{a}}$ & $685^{\mathrm{a}}$ \\
membrane $\left(\mu \mathrm{m}^{2} /\right.$ cell) & $620-768$ & $598-750$ & $603-768$ \\
Agranular endoplasmic & $256^{\mathrm{a}}$ & $323^{\mathrm{a}}$ & $268^{\mathrm{a}}$ \\
reticulum $\left(\mu \mathrm{m}^{2} /\right.$ cell) & $220-293$ & $266-380$ & $210-325$ \\
Granular endoplasmic & $638^{\mathrm{a}}$ & $1332^{\mathrm{b}}$ & $1269^{\mathrm{b}}$ \\
reticulum $\left(\mu \mathrm{m}^{2} /\right.$ cell) & $545-731$ & $1117-1547$ & $1101-1437$ \\
\hline Values are means with $95 \%$ confidence limits below for 6 cows. Mean values with \\
different letter superscripts in the same row are significantly different $(P<0.05)$.
\end{tabular}

by these cells over a 72-h culture period. Each steroid caused a dose-related suppression in the mean production of progesterone. The oestrogens inhibited progesterone production from the start of the culture period, whereas the androgens only inhibited after the first $24 \mathrm{~h}$ of culture.

\section{Influence of follicular health on morphological characteristics of granulosa cells}

Morphometric analysis was used to quantitate the morphological characteristics of freshly harvested granulosa cells from 3 to $8 \mathrm{~mm}$ diameter follicles taken from 6 cows between Days -3 and -1 of the oestrous cycle. Follicular health significantly influenced mean cell volume, and the mean surface area of the plasma and nuclear membranes, and the granular endoplasmic reticulum (Table 2). Follicle health had no significant effect on the mean volumes of the major subcellular components (nucleus, lipid, lysosomes, vacuoles, mitochondria, agranular endoplasmic reticulum and microfilaments), each of which had a mean volume of $\sim 10-20 \mu \mathrm{m}^{3} /$ cell, except for the nuclei which had mean values of about $150-200 \mu \mathrm{m}^{3} /$ cell.

Irrespective of follicle health freshly harvested granulosa cells appeared spherical with a relatively smooth surface when viewed by scanning electron microscopy. After culture for $24 \mathrm{~h}$, cells from non-atretic follicles were still spherical, but many had surface 'blebs'. In contrast, cells from atretic follicles were generally 'flattened' in appearance, and large amounts of intercellular connective tissue were evident. The appearance of cells from atretic follicles changed little when the culture period was extended beyond $24 \mathrm{~h}$. However, cells from non-atretic follicles gradually acquired the appearance of cells from atretic follicles, and by $72 \mathrm{~h}$ were indistinguishable from them. The inclusion of FSH $(100 \mathrm{ng} / \mathrm{ml})$ or dibutyryl cyclic AMP $(1.0 \mathrm{mM})$ in the culture medium markedly reduced the appearance of surface 'blebs' on cells from healthy follicles after $24 \mathrm{~h}$ of culture, but could not prevent them appearing like cells from atretic follicles over $72 \mathrm{~h}$ of culture.

\section{Discussion}

The present study demonstrates that follicular health has a major influence on the ability of granulosa cells from cow follicles to produce progesterone and oestradiol-17 $\beta$ in vitro. In non-atretic 
follicles, the production of these steroids by granulosa cells was also related to follicle size. The increasing daily production of progesterone, and the associated morphological changes, by cultured cells from non-atretic follicles are characteristic of cells undergoing luteinization (Channing \& Ledwitz-Rigby, 1974), as they start to express the characteristics of granulosa-luteal cells. Irrespective of follicle size, granulosa cells from atretic follicles displayed the characteristics of luteinized cells within $24 \mathrm{~h}$ of culture. Therefore, these cells, in contrast to cells from non-atretic follicles, may have already undergone some luteinization in vivo. This view would be consistent with the observation that irrespective of follicle size, progesterone concentrations in follicular fluid are significantly higher in atretic than in non-atretic follicles (Bellin \& Ax, 1984; McNatty et al., 1984a; Kruip $\&$ Dieleman, 1985). The studies with cyanoketone, an inhibitor of $3 \beta$-hydroxysteroid dehydrogenase, suggest that the differences in progesterone production between cells from non-atretic and atretic follicles may be a consequence of differences in the synthesis of pregnenolone, the precursor for progesterone.

The regulation of progesterone production by granulosa cells has been widely studied in several species, but usually without regard to the health of the follicles from which the cells were obtained. The present study indicates that steroids may have some importance in regulating progesterone production by granulosa cells from follicles of different health. Although testosterone failed to suppress progesterone production by granulosa cells from atretic follicles both androgens and oestrogens suppressed progesterone production by granulosa cells from non-atretic follicles in a dose-dependent fashion. The inhibitory effects of oestrogens have been shown previously for the cow (Fortune \& Hansel, 1979) and other species (see review by Hillier, 1985). However, studies with androgens in other species have generally shown a stimulatory effect on progesterone production by granulosa cells (Hillier, 1985), in contrast to the results of the present study. It could be argued that the inhibitory effects of testosterone and androstenedione might arise, at least in part, from their metabolism to oestradiol-17 $\beta$, though by Day 2 of culture the cells have lost most of their aromatase activity. This argument could not however account for the inhibitory effects of $5 \alpha$ dihydrotestosterone. Perhaps in non-atretic follicles, thecal androgens, produced in response to $\mathrm{LH}$, together with oestrogens produced by granulosa cell aromatization of these androgens, have a physiological role in limiting progesterone production by granulosa cells during follicular development in the cow. In large atretic follicles there is limited thecal androgen production in response to LH and granulosa cells from small and large atretic follicles have little aromatase activity (McNatty et al., 1984a; Table 1).

Although daily progesterone production by granulosa cells from non-atretic follicles increased with time in culture, production of oestradiol- $17 \beta$ declined to levels comparable to that of cells from atretic follicles. While this loss in oestradiol-17 $\beta$ synthetase activity may be an artefact of the culture system, resulting from differential cell loss, it is perhaps more likely a consequence of the luteinization process. Bovine luteal cells themselves have a very high capacity for progesterone biosynthesis, but only a very limited ability to aromatize androgens to oestradiol-17 $\beta$ (Henderson \& Moon, 1979). Collectively, the results of this study suggest that, in the presence of adequate amounts of progesterone precursor substrate, granulosa cells may have a natural tendency to produce large amounts of progesterone, but only a limited tendency to metabolize androgens to oestradiol-17ß. In non-atretic follicles, granulosa cells may be under considerable regulatory pressure which acts to suppress this natural tendency to secrete progesterone, and in larger follicles drives oestradiol-17 $\beta$ production. When these regulatory pressures are reduced, e.g. during follicular atresia, or when the granulosa cells are placed in culture, then the cells revert to a more natural state in terms of steroid production. Perhaps part of the luteinization process during corpus luteum formation is the removal of constraints thereby allowing the granulosa cells to display their inherent tendency to secrete progesterone, as suggested by Rothchild (1981).

Although follicular health had a major influence on progesterone and oestradiol-17 $\beta$ production by granulosa cells, morphometric analysis revealed relatively few subcellular differences between cells from non-atretic and atretic follicles. In particular, no ultrastructural differences were 
evident in the mitochondria or agranular endoplasmic reticulum (the subcellular sites of progesterone and oestradiol-17 $\beta$ biosynthesis respectively). As follicles became atretic significant increases occurred in the surface areas of the nuclear and plasma membranes. This was not always accompanied by increases in the volume of the organelle, which suggests that these membranes were becoming more convoluted. Such changes together with minimal organelle changes are indicative of cellular swelling (Cheville, 1976). Whether this swelling is expressed in vivo or is an artefact of the treatment before fixation is unclear. Nevertheless, it does reflect some difference(s) in membrane structure and/or function between granulosa cells from follicles of different health. This in turn could influence the steroidogenic abilities of these cells.

We thank the National Institute of Arthritis, Diabetes and Digestive and Kidney Diseases, Bethesda, U.S.A. for providing the gonadotrophins used in this study; Mr R. M. Goodwin, Mr H. H. Gwilliam and Mr I. C. Scott for monitoring oestrous activity in the cows; Mr G. Aliprantis for assistance in obtaining ovaries from Wellington Abattoir; and Sarah Best for statistical advice concerning morphometric analysis.

\section{References}

Abercrombie, M. (1946) Estimation of nuclear population from microtomic sections. Anat. Rec. 94, 239-247.

Bellin, M.E. \& Ax, R.L. (1984) Chondroitin sulfate: an indicator of atresia in bovine follicles. Endocrinology $114,428-434$.

Channing, C.P. \& Ledwitz-Rigby, F. (1974) The corpus luteum studied in vitro. In Physiology and Genetics of Reproduction, part B, pp. 353-370. Eds E. M. Coutinho \& F. Fuchs. Plenum Publishing Corporation, New York.

Cheville, N.F. (1976) In Cell Pathology, ch. 2, pp. 20-24. Iowa State University Press, Ames.

Eagle, A. (1959) Amino acid metabolism in mammalian cell cultures. Science, N.Y. 130, 432-437.

Fortune, J.E. \& Hansel, W. (1979) The effects of $17 \beta$ estradiol on progesterone secretion by bovine theca and granulosa cells. Endocrinology 104, 1834-1838.

Henderson, K.M. \& Moon, Y.S. (1979) Luteinization of bovine granulosa cells and corpus luteum formation associated with loss of androgen aromatizing ability. J. Reprod. Fert. 56, 89-97.

Henderson, K.M., Willcox, D.L. \& Bruce, N.W. (1983) Effect of infusion of PGI-2, 6-keto-PGF-1 $\alpha$ and PGF- $2 \alpha$ on luteal function in the pregnant rat. $J$. Reprod. Fert. 69, 11-16.

Henderson, K.M., Franchimont, P., Charlet-Renard, Ch. \& McNatty, K.P. (1984) Effect of follicular atresia on inhibin production by bovine granulosa cells in vitro and inhibin concentrations in the follicular fluid. $J$. Reprod. Fert. 72, 1-8.

Hillier, S.G. (1985) Sex steroid metabolism and follicular development in the ovary. In Oxford Reviews of Reproductive Biology, vol. 7, pp. 168-222. Oxford University Press.

Kruip, Th.A.M. \& Dieleman, S.J. (1985) Steroid hormone concentrations in the fluid of bovine follicles relative to size, quality and stage of the oestrous cycle. Theriogenology 24, 395-408.
Lowry, O.H., Rosebrough, N.J., Farr, A.L. \& Randall, R.S. (1951) Protein measurement with the Folin phenol reagent. J. biol. Chem. 193, 265-275.

MeNatty, K.P., Hillier, S.G., van den Boogaard, A.J.M., Trimbos-Kemper, T.C.M., Reichert, L.E. \& van Hall, E.V. (1983) Follicular development during the luteal phase of the human menstrual cycle. J. clin. Endocr. Metab. 56, 1022-1034.

MeNatty, K.P., Heath, D.A., Henderson, K.M., Lun, S., Hurst, P.R., Ellis, L.M., Montgomery, G.W., Morrison, L. \& Thurley, D.C. (1984a) Some aspects of thecal and granulosa function during follicular development in the bovine ovary. J. Reprod. Fert. 72, 39-53.

McNatty, K.P., Heath, D.A., Lun, S., Fannin, J.M., McDiarmid, J.M. \& Henderson, K.M. (1984b) Steroidogenesis by bovine theca interna in an in vitro perifusion system. Biol. Reprod. 30, 159-170.

Patterson, M.K. (1979) Measurement of growth and viability of cells in culture. In Methods in Enzymology, vol. 58, pp. 141-152. Eds W. B. Jakoby \& I. H. Pastan. Academic Press, New York.

Rothchild, I. (1981) The regulation of the mammalian corpus luteum. Recent Prog. Horm. Res. 37, 183-298.

Weibel, E.R. (1980a) Point counting methods. In Stereological Methods, vol. 1: Practical Methods for Biological Morphometry, pp. 101-134. Academic Press, London.

Weibel, E.R. (1980b) Numerical density: shape and size of particles. In Stereological Methods, vol. 2: Theoretical Foundations, pp. 140-174. Academic Press, London.

Williams, M.A. (1977) Stereological techniques. In Quantitative Methods in Biology, pp. 5-84. Ed. A. M. Glauert. North Holland Publishing Co., Amsterdam.

Williams, M.A. \& Cope, G.H. (1981) Membrane dynamics in the parotid acinar cell during regranulation: a stereological study following isoprenalineinduced secretion. Anat. Rec. 199, 389-401. 